\title{
Edward Friedman, Paul Pickowicz and Mark Selden, Revolution, Resistance, and Reform in Village China
}

Lucien Bianco

\section{CpenEdition}

\section{Journals}

Édition électronique

URL : http://journals.openedition.org/chinaperspectives/2343

DOI : $10.4000 /$ chinaperspectives. 2343

ISSN : 1996-4617

Éditeur

Centre d'étude français sur la Chine contemporaine

Édition imprimée

Date de publication : 15 septembre 2007

ISSN : 2070-3449

Référence électronique

Lucien Bianco, «Edward Friedman, Paul Pickowicz and Mark Selden, Revolution, Resistance, and Reform in Village China », China Perspectives [En ligne], 2007/3 | 2007, mis en ligne le 09 avril 2008, consulté le 24 septembre 2020. URL : http://journals.openedition.org/chinaperspectives/2343 ; DOI : https://doi.org/10.4000/chinaperspectives.2343

Ce document a été généré automatiquement le 24 septembre 2020

(c) All rights reserved 


\section{Edward Friedman, Paul Pickowicz and Mark Selden, Revolution, Resistance, and Reform in Village China}

Lucien Bianco

1 The previous book written by these three authors generated considerable enthusiasm. However, it was an enthusiasm I did not share, and while this current volume may pass unnoticed, I find it much better. The two books discuss the same village: Wugong, in the xian of Raoyang (Hebei), some 200 kilometres south of Beijing. Wugong is a model village, famed and cherished for having founded a co-operative at the height of the Sino-Japanese war. The previous volume largely covered the 1940s and 1950s, while the current one begins in the middle of the famine of the Great Leap Forward and takes us all the way through to the early years of 2000 .

2 While I intend to distinguish between the two books, they do share an initial commonality. Both are presented as chronicles, as local histories which recount the events in step by step detail and relate their impact on the lives of the villagers. This approach entails a certain lack of focus, a succession of small paragraphs, each of which offers an assessment of a political, social or anthropological nature. These insights are placed into their chronological context, but almost never within a thematic context. Another consequence of this method (the choice of simply telling things in the order in which they were experienced) is a repetition of the same themes, which may have first been evoked due to such and such local incident, and then are brought up again when a similar incident occurs a decade or a generation later. A more systematic analysis of a few large issues or, at the very least, a conclusion would have been welcome. On the other hand, the authors' intentional discretion helps to create a document which is not overly constructed, leaving the reader free to draw his or her own conclusions.

3 The authors have, of course, drawn their own. It is precisely their point of view which creates, in my view, the great difference with the first volume: they have lost their 
illusions. This new volume is clear and overpowering, but nevertheless complex. This is best illustrated through the themes of patronage and clientelism, and the privileges which have been perpetuated from Mao's revolutionary era through to the current post-revolutionary era. This topic was not absent from the first volume, since it is to its leaders that the model village of Wugong owes its privileges and fame, but it is a recurring theme in the second volume, with the authors detailing not only the favours but also the denunciations and recantations which disgraced leaders are forced into by changes in the Party line, beginning with Geng Changsuo (1900- 1985), Wugong's established head.

4 The story of the successive republication of books dedicated to glorifying Wugong is frankly comic. In 1963, around the time of the twentieth anniversary of the cooperative's foundation, the xian Communist Party secretary objected to the publication of a chapter asserting that the founder had created the co-operative several months before Mao's call to "organise yourselves." The secretary defended his objection thus: "As if he could be more intelligent than President Mao! This is a fundamental error!" Ten years later, for the thirtieth anniversary, things became even more complicated: the criticism of Lin Biao had brought a less militant line to prominence, but Mao had just made it clear that he would not give up his whims. Embarrassed, the editors were unable to tell if it was better to laude or to criticise non-collective activities, a source of prosperity but also of individual enrichment. One is always better off sticking to received certainties: Geng removed every single word written by an author who had been denounced during the Cultural Revolution, and deleted all positive references to the Soviet Union and negative references towards the United States. The 1963 volume praises the aid given by Wugong to famine-stricken children in the area as well as a campaign carried out against the traditional funeral, deemed costly and superstitious. In 1973, these two citations disappear: it was not in good form to recall the difficult moments of the Great Leap Forward, and even less to bring up a campaign launched by Chen Boda who had since been imprisoned. In 1983, for the fortieth anniversary, things were clear: Wugong had always wanted and promoted reform (...) it is just that its leaders had resisted this push as much and for as long as they could.

5 All adult members of the Geng family have their party card, and almost all their salaries are paid by the state. One Geng daughter rises as if "in a helicopter" through the Party's provincial hierarchy, while one grandson becomes the political heir to his grandfather at the local level. The villagers are well aware that reform has not changed the political regime, that privileges are perpetuated, and that access to power can make one rich.

6 Another granddaughter, raised in Beijing, where she received her higher education, now lives in Sydney and is married to an Australian. When she returns to the village, the backwardness and poverty shock her, and she asks herself how she might possibly live and survive in such conditions, but she never judges her family, she is content to love them. And we should try to emulate her rather than condemn the opportunistic leader, Geng. The authors avoid this condemnation, as does Huang Shumin, who began by disliking this village leader but who then learned to understand and appreciate him ${ }^{1}$. Geng, who was forced to sell one of his daughters during the 1943 famine, owes everything to the revolution, and it is not only out of a kind of self-interested slavish following that he makes the unconditional exclamation: "Everything that President Mao says, I will do." He subscribed to the "hard" Maoist revolutionary line, certainly because the reformist modernisers were often rapped across the knuckles, but also by 
conviction. During the Great Leap Forward, he nevertheless refused to undertake the posting of productivity gains prescribed by propaganda, which caused Wugong to be dropped for a time from the list of model villages. During the shortages, he did not steal. While he made his own family's fortune, he himself lived simply. He is authoritarian without mistreating the villagers. He is satisfied with preventing them from growing rich themselves by forcing them to cultivate non-lucrative crops such as cereals and cotton and by banning more lucrative crops and other related activities as sources of "capitalist profit." This is the only thing for which the villagers reproach him, to the great displeasure of the Red Guards who came from Beijing expressly to unseat him. These Red Guards had hoped to make the villagers say that he had betrayed the revolution and socialism, but his critics stubbornly insisted in their reproaches of him for having sacrificed their interests to those of the state, following Mao's line exactly!

7 The book abounds in anecdotes, such as that of the unfortunate boy whose parents who believed it would be good to give him at birth the first name of Xuesu ("to take the Soviet Union as a model"). Twelve or fifteen years later, they tried in vain to rename him Pixiu ("critic of revisionism") but nothing could be done: he became the laughingstock and scapegoat of his comrades. The 1970 visit of Li Xuefeng, temporary member of the Political Bureau has remained famous in the village for a reason other than the dignitary's high rank. On the first evening one of Li's deputies complained about the din raised by the guard dogs who had been made anxious by the presence of outsiders in the village. The next morning, without waiting for the order to exterminate the pooches, their owners rushed to the butcher to sell them. Years later, the blessing of cheap and easily available dog meat bestowed by $\mathrm{Li}$ is still fondly remembered.

The villagers react in their own way to the avalanche of changing policies poured down on them from up high. For example, the denunciation of Mao's successor, Lin Biao, as another Confucius: in the presence of such deeply baffling mysteries it is better to play the fool. The aforementioned Lin Biao had cultivated a group of "red successors" chosen among the young militia members, giving preference to the sons of cadres. After his posthumous denunciation, Jiang Qing advocated giving preference to young girls, emphasising equality between the sexes. Not to be left behind, Wugong named an activist to the Party Committee: as if by chance, she was the wife of one of Geng's grand sons. This sort of nepotism does not do much to make the villagers laugh (they are no longer shocked). It is the incongruous presence of a woman on the Party Committee that catches their attention: "She's like a mother-in-law, no good for anything." Jiang Qing's condemnation years later strengthens their misogyny.

Contempt of women, who should stay in their place, serving men and then eating the leftovers, suspicion of the kids with big city educations ("the first year, still one of ours; the second year, a stranger; the third year, no longer recognising his or her parents"), jingoism and xenophobia: these are the features which colour the village's reception of a certain nationalist campaign (or the defeat of a Japanese investor's ventures in Wugong; he was quickly forced to pack his bags), Mao's attacks on "stinking intellectuals" or, conversely, his tirades-more than his efforts-in favour of the other "half of the sky." Of course these characteristics cannot fully define a village caught in the criss-cross of contradictory currents: during the reform era, the nostalgia for the order-and, without jest, the purity-of the Maoist era is widespread, above all among 
the old, with the generation gap as deep and unsounded as the Confucianism of Lin Biao.

10 Nothing is one-sided, or caricatural in this book, not even the condemnation of Maoism or its freeloading inferior successors. It is a local history told with a critical distance but never bereft of sympathy. It is a sober, concise, incisive account, quite often simply complemented by a final line or concluding phrase. The villagers of Wugong, including Boss Geng (as our three authors call him with affectionate irony), have taken their place in the pantheon of the heroes and guinea-pigs of this revolutionary tragedy.

Translated by Jonathan Hull

\section{NOTES}

1. Huang Shumin, The Spiral Road, Change in a Village through the Eyes of a Communist Party Leader, Boulder, Westview Press, 1989. 